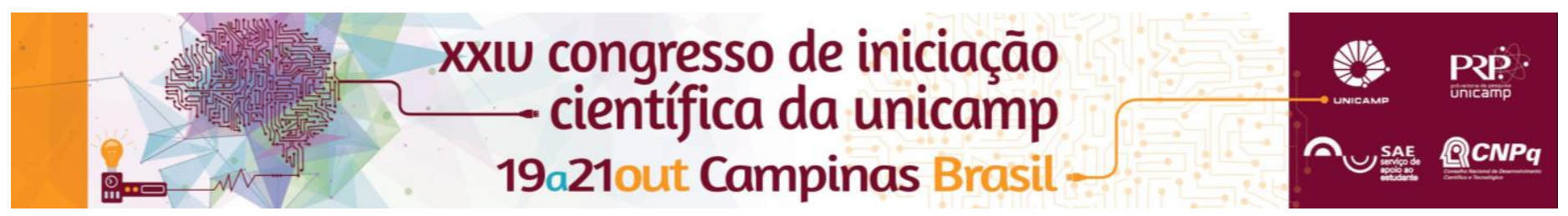

\title{
Use of ozone in reducing the microbiological load on lettuce at different temperatures
}

\author{
Renan Ciotto Pinton (IC), Raquel Cavasini (PG), Antônio Carlos de Oliveira Ferraz (PQ).
}

\begin{abstract}
Ozone is a viable alternative to sanitization of agricultural products due to its highly oxidative capacity, rapid degradation and absence of residues in food and even in the environment. Thus, this work was developed aiming to design and construct an ozone application system to investigate possible reduction on lettuce ( American variety) leaves surface at temperatures of $5^{\circ} \mathrm{C}, 15^{\circ} \mathrm{C}$ and $25^{\circ} \mathrm{C}$. At the end of the storage period the greater efficiency in ozone action in reducing microbial load was for the concentration of $3 \mathrm{ppm}$ at $15^{\circ} \mathrm{C}$. As for quality indicators, treatments showed difference only in soluble solids, with a significant reduction after exposure to the gas. The appearance was affected by staining the leaves with small brown spots in all treatments with ozone after the fourth day. We conclude that although the ozone present efficiency in microbial reduction its over exposure to it significantly reduces quality. Therefore, it is of fundamental importance to know the product limits to avoid damage.
\end{abstract}

Key words: ozone , microorganisms, Lactuca sativa.

\section{Introduction}

The use of ozone for disinfection is a technology that awakens the increasing attention of the food industry in recent years, due to its distinct antimicrobial properties against bacteria, fungi and vírus ${ }^{1}$. Ozonation is considered a safe method because, in contrast to the chlorination does not leave chemical residues. The study aimed to design and construct a gaseous ozone application system for lettuce (Lactuca sativa ) since it is one of the most important vegetable in the Brazilian market to be consumed "in natura". Hence the importance of acting in the control of microorganisms and pathogens occurring after harvest to maintain its quality and sanity.

\section{Results and Discussion}

The proposed system consisted of a cylinder of oxygen (99\%), a corona ozone generator and a storage chamber for product exposure to the gaseous mixture. The flow of ozone used in the experiment was $1 \mathrm{I} / \mathrm{min}$ and the lettuce leaves were kept in the hermetically sealed chamber for a period of 3 minutes. They were exposed to combinations of two different concentrations of gas ( 3 and $1.5 \mathrm{ppm}$ ) and three temperatures $\left(25^{\circ} \mathrm{C}, 15^{\circ} \mathrm{C}\right.$ and $\left.5^{\circ} \mathrm{C}\right)$. Physical chemical ${ }^{2}$ analyzes were performed to quantify the effects on product quality after ozone applications, and microbiological analysis to investigate the gas mixture efficiency in controlling molds and yeasts ${ }^{3}$. At the end of the trial period lettuces showed alterations only to the soluble solids, but it was observed a slight darkening of the leaves exposed to ozone. According to count the number of colony forming units (CFU), treatment with $3 \mathrm{ppm}$ to $15^{\circ} \mathrm{C}$ was the most efficient in reducing $84 \%$ contamination levels.
Table 1. Microbiological analysis - Yeast and Molds.

\begin{tabular}{cccc}
\hline \multirow{2}{*}{ Treatment } & \multicolumn{3}{c}{ Yeasts and Molds $\left(\mathbf{1 0} \mathbf{U F C ~}^{\mathbf{~}} \mathbf{~}^{\mathbf{1}} \mathbf{)}\right.$} \\
\cline { 2 - 4 } & Dia 0 & Dia 2 & Dia 4 \\
\hline Control & 2,5 & 3,8 & 5,3 \\
T1 & - & 8,5 & 15,0 \\
T2 & - & 3,0 & 5,6 \\
T3 & - & 7,0 & 14,0 \\
T4 & - & 6,7 & 12,0 \\
T5 & - & 0,3 & 0,4 \\
T6 & - & 0,7 & 6,6 \\
\hline
\end{tabular}

UFC $\mathrm{ml}^{-1}=$ Colony Forming Units; Treatments T1, T2 e T3 = concentration 1,5 ppm of ozone at temperature of $25^{\circ} \mathrm{C}, 15^{\circ} \mathrm{C}$ e $5^{\circ} \mathrm{C}$ respectivamente; Treatmentss $\mathrm{T} 4$, T5 e $\mathrm{T} 6$ = concentration of $3 \mathrm{ppm}$ of ozone at temperature de $25^{\circ} \mathrm{C}, 15^{\circ} \mathrm{C}$ e $5^{\circ} \mathrm{C}$ respectively.

\section{Conclusions}

The data obtained from the trial showed that ozone is a suitable option for the control of microorganisms, reducing the yeast and mold load, without affecting the physical and chemical characteristics and the appearance of the lettuce leaves.

\section{Acknowledgement}

At FEAGRI / Unicamp for the research infrastructure and CNPq for the scholarship granted.

${ }^{1}$ SOPHER, C.D.; BATTLES, G.T.; JOHNSON, D. The utilization of ozone for treating vegetable processing lines. Ozone: Science \& Engineering, v. 31, p. 309315, 2009.

${ }^{2}$ ASSOCIATION OF OFFICIAL ANALYTICAL CHEMISTRY. Official methods of analysis of the Association of Official Analytical Chemistry. Arlington, Virginia, USA. 16 ed. v.II, 1995.

${ }^{3}$ SILVA, N.; JUNQUEIRA, V.C.A.; SILVEIRA, N.F.A.; TANIWAKI, M.H.; SANTOS, R.F.S.; GOMES, R.A.R. Manual de Métodos de Análise Microbiológica de Alimentos. $3^{a}$ edição. São Paulo: Livraria Varela, 2007. 624p. 